
\title{
Impact of mutational studies on the diagnosis and the outcome of high-risk myelodysplastic syndromes and secondary acute myeloid leukemia patients treated with 5-azacytidine
}

\author{
Marta Cabezónn ${ }^{1,2}$, Joan Bargay ${ }^{3}$, Blanca Xicoy ${ }^{1}$, Olga García ${ }^{4}$, Josep Borrás ${ }^{3}$, Mar \\ Tormo $^{5}$, Sílvia Marcé ${ }^{1}$, Carme Pedro ${ }^{6}$, David Valcárcel7, Maria-José Jiménez ${ }^{1}$, \\ Ramón Guàrdia ${ }^{8}$, Laura Palomo ${ }^{4}$, Salut Brunet ${ }^{9}$, Ferran Vall-Llovera ${ }^{10}$, Antoni \\ Garcia $^{11}$, Evarist Feliu ${ }^{1}$ and Lurdes Zamora ${ }^{1}$; On Behalf of the CETLAM Group \\ ${ }^{1}$ Hematology Service, ICO Badalona-Hospital Germans Trias i Pujol, Josep Carreras Leukaemia Research Institute, Universitat \\ Autònoma de Barcelona, Badalona, Spain \\ ${ }^{2}$ Departament de Medicina, Universitat Autònoma de Barcelona, Badalona, Spain \\ ${ }^{3}$ Hematology Service, Hospital Son Llàtzer, Mallorca, Spain \\ ${ }^{4}$ Josep Carreras Leukemia Research Institute, Campus Germans Trias i Pujol, Universitat Autònoma de Barcelona, Badalona, \\ Spain \\ ${ }^{5}$ Hematology Service, Hospital Clínic de Valencia, Valencia, Spain \\ ${ }^{6}$ Hematology Service, Hospital del Mar, Barcelona, Spain \\ ${ }^{7}$ Hematology Service, Hospital Vall d'Hebron, Barcelona, Spain \\ ${ }^{8}$ Hematology Service, ICO Girona-Hospital Josep Trueta, Girona, Spain \\ ${ }^{9}$ Hematology Service, Hospital de Sant Pau, Barcelona, Spain \\ ${ }^{10}$ Hematology Service, Hospital Mútua de Terrassa, Terrassa, Spain \\ ${ }^{11}$ Hematology Service, Hospital Arnau de Vilanova, Lleida, Spain \\ Correspondence to: Lurdes Zamora, email: Izamora@iconcologia.net
}

Keywords: myelodysplastic syndromes; secondary acute myeloid leukemia; targeted deep sequencing; prognostic factors; 5-azacytidine

Received: December 06, $2017 \quad$ Accepted: March 05, $2018 \quad$ Published: April 10, 2018

Copyright: Cabezón et al. This is an open-access article distributed under the terms of the Creative Commons Attribution License 3.0 (CC BY 3.0), which permits unrestricted use, distribution, and reproduction in any medium, provided the original author and source are credited.

\section{ABSTRACT}

Myelodysplastic syndromes (MDS) are stem cell disorders caused by various gene abnormalities. We performed targeted deep sequencing in 39 patients with high-risk MDS and secondary acute myeloid leukemia (SAML) at diagnosis and followup (response and/or relapse), with the aim to define their mutational status, to establish if specific mutations are biomarkers of response to 5-azacytidine (AZA) and/or may have impact on survival. Overall, $95 \%$ of patients harbored at least one mutation. TP53, DNMT3A and SRSF2 were the most frequently altered genes. Mutations in TP53 correlated with higher risk features and shorter overall survival (OS) and progression free survival (PFS) in univariate analysis. Patients with SRSF2 mutations were associated with better OS and PFS. Response rate was 55\%; but we could not correlate the presence of TET2 and TP53 mutations with AZA response. Patients with SAML presented more variations than patients with high-risk MDS, and usually at relapse the number of mutations increased, supporting the idea that in advanced stages of the disease there is a greater genomic complexity. These results confirm that mutation analysis can add prognostic value to high-risk MDS and SAML patients, not only at diagnosis but also at follow-up. 


\section{INTRODUCTION}

Myelodysplastic syndromes (MDS) are a group of myeloid neoplasms originated in hematopoietic stem cells, characterized by cytopenias, dysplasia in one or more cell lines, ineffective hematopoiesis and an increased risk of progression to secondary acute myeloid leukemia (sAML) $[1,2]$. The outcome of MDS patients is extremely variable with median overall survival (OS) ranging from over 5 years to less than 6 months [3].

Recurrent chromosomal aberrations have been linked with distinct outcomes and are one of the most important risk factors when patients are stratified according to their risk level before therapy. However, approximately $50 \%$ of patients with AML or MDS have a normal karyotype and lack recurrent cytogenetic abnormalities, which suggests the implication of other molecular events in the pathogenesis of these diseases [4].

Over the past decade, the application of new highthroughput technologies to the study of MDS has led to the identification of several recurrently mutated genes in these disorders [5-7] and somatic gene mutations have been found to be more common than previously expected. The most common mutations found in MDS occur in genes involved in RNA splicing (including SF3B1, SRSF2, U2AF1 and ZRSR2) [8] and epigenetic regulators (including TET2, ASXL1 and DNMT3A) [9]. Several regulators of signal transduction (NRAS, $J A K 2)$ and transcription factors $(R U N X 1, T P 53)$ are also frequently mutated in MDS. The complex patterns of associations between gene mutations have revealed epistatic interactions between spliceosome components and epigenetic modifiers in MDS [10].

Some of the mutated genes identified using these high-throughput techniques have been shown to provide important prognostic information. For example, mutations in ASXL1, TP53,EZH2, ETV6 and RUNX1 have been described to be predictors of poor OS in patients with MDS, independently of the already established risk factors [11].

This genetic variability together with the diversity in the clinical presentation of MDS, emphasizes the need for tailored treatment of patients. Current therapy options comprise supportive therapy, growth factor therapy, chemotherapy, immunotherapy, epigenetic therapy and allogeneic stem-cell transplantation (ASCT) $[12,13]$. To date, ASCT is the only treatment considered as curative; however, due to high toxicity of the treatment and the advanced age of many MDS patients at diagnosis, it can only be applied on a limited subset of cases. Hypomethylating agents (HMAs) like 5-azacytidine (AZA) and decitabine have shown a high efficacy in MDS, especially in high-risk MDS patients, remaining the mainstay of treatment in this subtype of MDS, however only half of all patients will respond to these drugs [14-16]. The reasons underlying AZA resistance are unknown, and few alternatives exist for non-responders. Recently, it has been said that primary AZA resistance is intricately linked to cell cycle quiescence of hematopoietic progenitor cells (HPC) in non-responders before treatment, and AZA response is associated with the induction of an inflammatory response in HPCs in vivo [17]. Even so, there is a lack of biological markers that predict which patients will respond to HMAs, so more studies focusing in specific subtypes of MDS are needed.

In this study, we performed a mutation analysis of 83 genes involved in myeloid malignancies in a cohort of high-risk MDS and sAML patients treated uniformly with AZA according to a prospective multicenter protocol from the CETLAM Group. The aim of the study was to define the mutational status at diagnosis, to identify the relationship between genotype and treatment response, to establish if any gene mutation could be used as a prognostic marker for response and survival and to study the evolution of mutations during patients' follow-up (response and relapse).

\section{RESULTS}

\section{Patient characteristics and treatment given}

A total of 39 patients with high-risk MDS and sAML were studied. Main clinical and biological characteristics of patients are summarized in Table 1. Median age at diagnosis was 71 years (range 55-83) and the series included $29(74 \%)$ males and $10(26 \%)$ females. According to the $2008 \mathrm{WHO}$ classification cases were diagnosed of refractory anemia with ring sideroblasts (RARS) $(n=1)$, refractory cytopenia with multilineage dysplasia and ring sideroblasts (RCMD-RS) $(n=1)$, refractory cytopenia with multilineage dysplasia (RCMD) ( $n=5,13 \%)$, refractory anemia with excess of blasts-1 (RAEB-1) $(n=9,23 \%)$, refractory anemia with excess of blasts-2 (RAEB-2) $(n=14,36 \%)$ and sAML $(n=9$, $23 \%$ ). Patients risk stratification was made according to the Revised International Prognostic Scoring System (IPSS-R) score and all patients belonged to intermediate, high or very high-risk groups (Table 1). All patients were treated with AZA (at a dose of $75 \mathrm{mg} / \mathrm{m}^{2} / \mathrm{d}$ for 7 days, 5-22 , every 4 weeks). The median number of AZA cycles was 6 (range 1-36).

\section{Conventional cytogenetics}

An informative result for conventional cytogenetics (CC) studies at diagnosis was obtained in all patients. Eight $(21 \%)$ patients had a normal karyotype or a loss of chromosome Y. The rest of patients $(79 \%)$ had an abnormal karyotype, being in most of cases a complex karyotype. 
Table 1: Main clinical and hematological characteristics of high-risk MDS and sAML patients at diagnosis $(n=39)$

\begin{tabular}{|c|c|c|}
\hline Variable & Median (range) & $N=39(\%)$ \\
\hline $\begin{array}{l}\text { Age, years } \\
<70 \mathrm{y} \\
\geq 70 \mathrm{y}\end{array}$ & $71(55-83)$ & $\begin{array}{l}18(46) \\
21(54)\end{array}$ \\
\hline $\begin{array}{l}\text { Gender } \\
\text { Male } \\
\text { Female }\end{array}$ & & $\begin{array}{l}29(74) \\
10(26)\end{array}$ \\
\hline $\begin{array}{l}\text { WHO classification } \\
\text { RARS } \\
\text { RCDM-RS } \\
\text { RCMD } \\
\text { RAEB-1 } \\
\text { RAEB-2 } \\
\text { SAML }\end{array}$ & & $\begin{array}{c}1(2.5) \\
1(2.5) \\
5(13) \\
9(23) \\
14(36) \\
9(23)\end{array}$ \\
\hline $\begin{array}{l}\text { Hemoglobin level, g/dL } \\
<10 \mathrm{~g} / \mathrm{dL} \\
\geq 10 \mathrm{~g} / \mathrm{dL}\end{array}$ & $9.1(6.5-12.5)$ & $\begin{array}{l}29(74) \\
10(26)\end{array}$ \\
\hline $\begin{array}{l}\text { Leukocyte count, } \times 10^{9} / \mathrm{L} \\
<4 \times 10^{9} / \mathrm{L} \\
>4 \times 10^{9} / \mathrm{L} \text { and }<11 \times 10^{9} / \mathrm{L} \\
\geq 11 \times 10^{9} / \mathrm{L}\end{array}$ & $2.9(1.1-50.2)$ & $\begin{array}{l}29(74) \\
8(21) \\
2(5)\end{array}$ \\
\hline $\begin{array}{l}\text { Platelet count, } \times 10^{9} / \mathrm{L} \\
<100 \times 10^{9} / \mathrm{L} \\
\geq 100 \times 10^{9} / \mathrm{L}\end{array}$ & $63(13-416)$ & $\begin{array}{l}28(72) \\
11(28)\end{array}$ \\
\hline $\begin{array}{l}\text { Neutrophil count, } \times 10^{9} / \mathrm{L} \\
<0.8 \times 10^{9} / \mathrm{L} \\
\geq 0.8 \times 10^{9} / \mathrm{L}\end{array}$ & $1.3(0.09-13.55)$ & $\begin{array}{l}13 / 36(36) \\
23 / 36(64)\end{array}$ \\
\hline $\begin{array}{l}\text { Blasts in } \mathrm{PB}, \% \\
<5 \% \\
\geq 5 \%\end{array}$ & $0(0-20)$ & $\begin{array}{c}32 / 38(84) \\
6 / 38(16)\end{array}$ \\
\hline $\begin{array}{l}\text { Blasts in BM, \% } \\
<20 \% \\
\geq 20 \%\end{array}$ & $11(0-36)$ & $\begin{array}{l}29(74) \\
10(26)\end{array}$ \\
\hline $\begin{array}{l}\text { Cytogenetics } \\
\text { Normal karyotype } \\
\text { Abnormal karyotype }\end{array}$ & & $\begin{array}{c}8(21) \\
31(79)\end{array}$ \\
\hline $\begin{array}{l}\text { IPSS risk group } \\
\text { Intermediate-1 } \\
\text { Intermediate-2 } \\
\text { High }\end{array}$ & & $\begin{array}{l}4(10) \\
19(49) \\
16(41)\end{array}$ \\
\hline $\begin{array}{l}\text { IPSS-R risk group } \\
\text { Intermediate } \\
\text { High } \\
\text { Very High }\end{array}$ & & $\begin{array}{l}5(13) \\
12(31) \\
22(56)\end{array}$ \\
\hline
\end{tabular}

BM: bone marrow; PB: peripheral blood; RAEB-1: refractory anemia with excess of blasts-1; RAEB-2: refractory anemia with excess of blasts-2; RARS: refractory anemia with ring sideroblasts; RCMD: refractory cytopenia with multilineage dysplasia. 


\begin{tabular}{lcc}
\hline & Number of patients & Average number of mutations per patient (range) \\
\hline SAML & 9 & $2.889(1-5)$ \\
RAEB-2 & 14 & $2.286(0-5)$ \\
RAEB-1 & 9 & $2(1-4)$ \\
RCMD & 5 & $2.2(1-4)$ \\
RCMD-RS & 1 & 5 \\
RARS & 1 & 1 \\
\hline
\end{tabular}

RAEB-1: refractory anemia with excess of blasts-1; RAEB-2: refractory anemia with excess of blasts-2; RARS: refractory anemia with ring sideroblasts; RCMD: refractory cytopenia with multilineage dysplasia; RCMD-RS: refractory cytopenia with multilineage dysplasia and ring sideroblasts; sAML: secondary acute myeloid leukemia.

\section{Targeted deep sequencing}

Targeted deep sequencing was performed in a total of 77 samples (39 at diagnosis, 17 follow-ups [6 at response and 11 at relapse] and $21 \mathrm{CD} 3+$ control samples), with a mean depth per base per sample of 737-fold (range: 84-971). More than $95 \%$ of the target sequences were analyzed with $>100$ independent reads and $>99 \%$ with at least 30 reads. After applying the mentioned filters in methodology, a mean of 2 variants per sample were called as high-probability somatic changes (range 0-5).

\section{Mutational analysis at diagnosis}

Across the entire cohort, $37 / 39$ (95\%) of patients harbored at least one mutation, affecting 35 of the 83 studied genes (in 48 genes we did not find any mutation). Details of all the detected variants are described in Supplementary Table 2. Due to the availability of the CD3+ control tissue, we were able to discard a mean of 2 variants per sample that had not been previously established as SNPs in public databases. Overall, the distribution of the number of mutations detected per patients was as follows, $12(31 \%)$ patients had 1 mutation, $11(28 \%)$ patients had 2 concurrent mutations, 2 (5\%) patients had 3 mutations, 7 (18\%) patients had 4 mutations and $5(13 \%)$ patients had 5 mutations (Supplementary Figure 1A). The distribution of mutations at diagnosis across patients' cohort is described in Figure 1. The most frequently affected genes (in $>10 \%$ of patients) were TP53 (49\%), DNMT3A (21\%) and SRSF2 (18\%); followed by TET2 (15\%) and U2AF1 (15\%). The list of frequencies of all the affected genes is described in Supplementary Table 3, and most of detected mutations corresponded to missense variants (Supplementary Figure 1B).

Regarding cytological category, the average of alterations detected in each category is detailed in Table 2, suggesting that patients with sAML present more variations than patients with RAEB-2, RAEB-1 or RCMD, even though this observation has to be taken with caution due to the number of patients in each category. We then examined the correlation between gene mutations

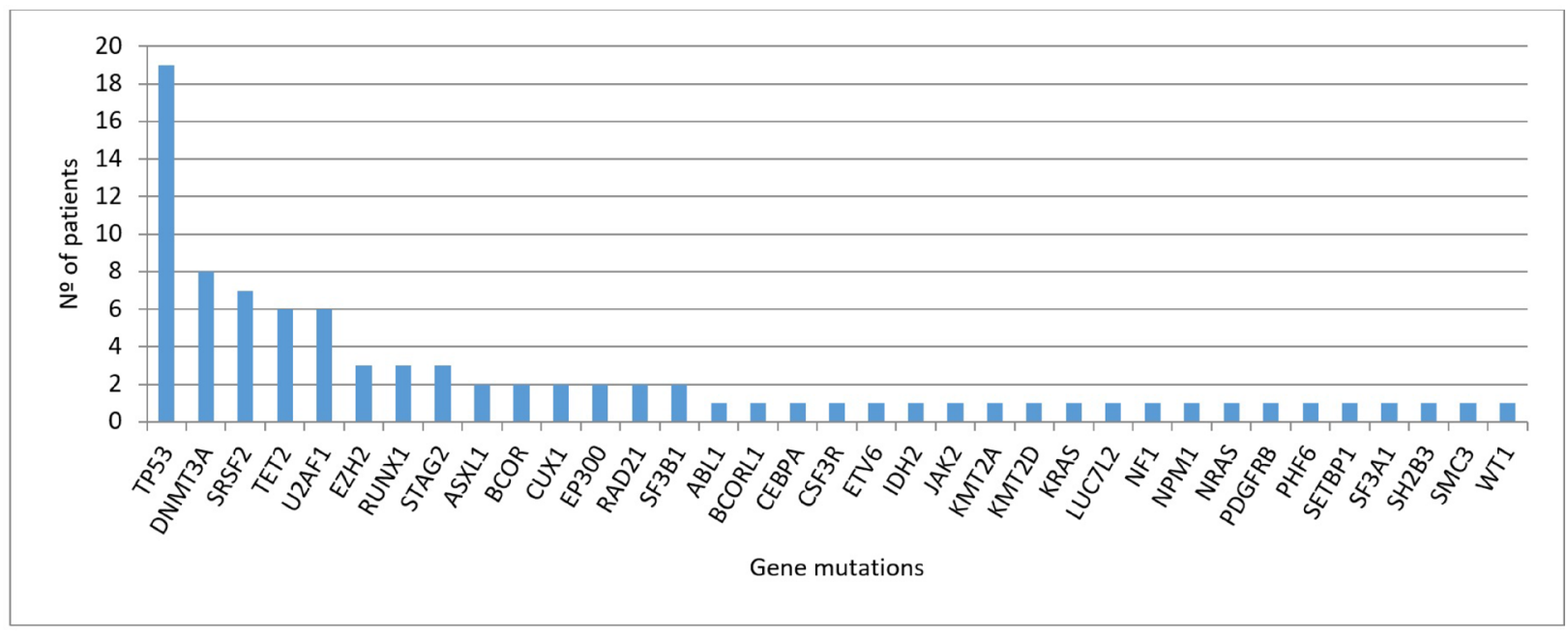

Figure 1: Distribution of mutations detected at diagnosis $(n=39$ patients). 
to identify possible functional interactions across the different affected genes. Due to the heterogeneity of mutated genes in the cohort of patients, we focused the statistical analyses only in those mutations detected in at least five patients. The only association found was the correlation between SRSF2 and TET2 mutations $(P=$ $0.006)$, and both mutations were mutually exclusive with TP53 mutations $(P=0.008)$.

\section{Relations between gene mutations and clinical variables}

We investigated the relation between mutations detected at diagnosis and main clinical and biological parameters of the patients, including age, gender, WHO subtypes, peripheral blood cell counts, percentage of blasts in peripheral blood and bone marrow, karyotype and IPSS-R categories. We observed more SRSF 2 mutations in patients with advanced age ( $>70$ years), even though it wasn't statistic significant (6 patients vs. 1 patient; $P$ $=0.098)$, and these mutations were associated with the absence of a complex karyotype $(P=0.010)$. U2AF1 mutations were associated with fewer neutrophils in peripheral blood $\left(<0.8 \times 10^{9} / \mathrm{L}\right)(P=0.003)$. Patients with TET2 wild-type were associated with less than $5 \%$ of blasts in peripheral blood $(P=0.021)$. Mutations in TP53 gene were associated with age, younger than 70 years $(P$ $=0.007)$, abnormal karyotype $(P=0.003)$, mainly with complex karyotype $(P<0.001)$, and with high-risk groups according to IPSS-R $(P=0.003)$.

We also studied the effect of TP53 mutations in the subset of patients that underwent ASCT $(n=5)$; three of them harbored a TP53 mutation and died in less than one year from MDS diagnosis. The other two patients, without TP53 mutations, remain alive after more than 3 years after diagnosis.

\section{Overall survival and progression free survival analysis}

We then explored the impact of clinical and biological data on patients' outcome. Median follow-up of alive patients was 11 months (range 0-68), and median OS and PFS $(95 \% \mathrm{CI})$ of the cohort were 1.1 years $(0.6,1.6)$ and 0.9 years $(0.8,1)$, respectively. Complex karyotype, IPSS-R risk group and hemoglobin were predictive of both OS and PFS (Table 3). In addition, there was a trend to worse PFS in patients with more than $5 \%$ of blasts in peripheral blood at diagnosis. Regarding genetic features, we did not find any association between the number of mutations and OS or PFS. Focusing on specifics genes, only mutations in TP53 were associated with shorter OS and PFS, while mutations in SRSF 2 correlated with better OS and PFS (Figure 2). Considering together SRSF2 and TP53 mutational status, patients could be stratified in three groups with significant different rates of OS and PFS (Figure 3).

Finally, we performed an adjusted multivariable Cox model including cytogenetic, IPSS-R and TP53 mutational status (Table 3). For both OS and PFS, TP53 mutational status was the only variable which remained significant.

\section{Predicting factors of response to hypomethylating therapy}

In our cohort of patients, 16 cases were classified as responders ( $8 \mathrm{CR}$ and $8 \mathrm{PR})$ to AZA at six months and 8 cases were classified as non-responders ( 2 stable disease and 6 treatment failure). There were 15 patients who died before the sixth cycle, but from those patients who received a minimum of 3 cycles of AZA we assessed their response according to the percentage of blasts in bone marrow and their transfusion requirements during these months. Afterwards, we could incorporate into the analysis seven more patients, six as non-responders, because their transfusions requirements did not decrease or because the blasts percentage increased under AZA treatment, and one patient was considered a responder because his transfusion requirements decreased with AZA treatment before being allografted. The other 8 patients received less than 3 AZA cycles and they were considered as no evaluable for response predicting factors.

The overall response rate (ORR) for evaluable patients was $55 \%$ (17/31). Univariate analysis of the impact of clinical characteristics and mutational status on response rates are summarized in Table 4. We did not find any clinical variable or gene mutation associated with treatment response.

\section{Mutational follow-up during response, relapse or AML progression}

Targeted deep sequencing was performed at response in six patients and at relapse or AML transformation in eleven patients (Table 5). In two patients the number of mutations at response decreased (patients ID32 and ID28), two patients maintained the number of mutations (patients ID13 and ID25) and in two more patients the number of mutations increased (patients ID7 and ID20), even though they had hematological improvement (Figure 4). The number of mutations detected per patient was the same between diagnosis and progression in 4/11 patients (ID4, ID16, ID23 and ID25) (36.4\%) and increased at time of relapse or AML progression in 6/11 patients (ID7, ID11, ID13, ID20, ID28 and ID32) (54.5\%). In patient ID32, the dominant clone observed at diagnosis disappeared in complete response but reappeared on relapse with mutations in other genes. Only one patient (ID21) did not present at relapse the mutation found at diagnosis or any other mutation from the studied gene panel. 
Table 3: Results of overall survival and progression free survival univariate and multivariate analyses

\begin{tabular}{|c|c|c|c|c|c|}
\hline \multicolumn{6}{|c|}{ UNIVARIATE ANALYSIS } \\
\hline \multirow[b]{2}{*}{ Variable } & \multirow[b]{2}{*}{ Categories } & \multicolumn{2}{|c|}{ Overall Survival (OS) } & \multicolumn{2}{|c|}{ Progression Free Survival (PFS) } \\
\hline & & $\begin{array}{c}\text { Median OS } \\
(95 \% \mathrm{CI})\end{array}$ & $P$ value & $\begin{array}{c}\text { Median PFS } \\
(95 \% \text { CI })\end{array}$ & $P$ value \\
\hline \multirow{2}{*}{ Karyotype } & Normal & $2.1(1.2,3)$ & \multirow{2}{*}{0.022} & $1.75(1.7,1.8)$ & \multirow{2}{*}{0.01} \\
\hline & Altered & $0.9(0.7,1)$ & & $0.8(0.6,1.1)$ & \\
\hline \multirow{2}{*}{$\begin{array}{l}\text { Hemoglobin } \\
\text { level }\end{array}$} & $<100$ & $0.9(0.5,1.2)$ & \multirow{2}{*}{0.028} & $0.8(0.5,1.1)$ & \multirow{2}{*}{0.029} \\
\hline & $\geq 100$ & $2.1(0.6,3.6)$ & & $1.7(0.3,3.1)$ & \\
\hline \multirow{3}{*}{ IPSS-R } & Intermediate & $2(0,4.6)$ & \multirow{3}{*}{0.026} & $1.2(0.2,2.2)$ & \multirow{3}{*}{0.005} \\
\hline & High & $1.7(1.2,2.2)$ & & $1.7(0.8,2.7)$ & \\
\hline & Very high & $0.5(0.1,1)$ & & $0.5(0.2,0.8)$ & \\
\hline \multirow{2}{*}{ TP53 } & WT & $1.7(0.9,2.6)$ & \multirow{2}{*}{0.005} & $1.4(0.6,2.2)$ & \multirow{2}{*}{0.002} \\
\hline & Mutated & $0.8(0.2,1.4)$ & & $0.7(0.3,1)$ & \\
\hline \multirow{2}{*}{$S R S F 2$} & WT & $0.9(0.7,1.2)$ & \multirow{2}{*}{0.043} & $0.9(0.7,1)$ & \multirow{2}{*}{0.007} \\
\hline & Mutated & $3.8(1.5,6.1)$ & & $3.7(1.5,5.9)$ & \\
\hline \multicolumn{6}{|c|}{ MULTIVARIATE ANALYSIS } \\
\hline \multirow{2}{*}{ Variable } & \multirow{2}{*}{ Baseline category } & \multicolumn{2}{|c|}{ Overall Survival (OS)* } & \multicolumn{2}{|c|}{ Progression Free Survival (PFS) } \\
\hline & & HR $(95 \%$ CI) & $P$ value & HR (95\% CI) & $P$ value \\
\hline TP53 & WT & $2.9(1.3,6.3)$ & 0.007 & $3.4(1.5,7.5)$ & 0.003 \\
\hline
\end{tabular}

\section{DISCUSSION}

MDS is a heterogeneous disease, and so are the genetic alterations more appellants, as they include gains or losses of chromosomal regions, mutations and epigenetic modifications [18-20]. Over the past few years, next-generation sequencing (NGS) has led to a revolution in the study of hematological malignancies, with remarkable efforts to characterize the mutational basis of these disorders. Focusing on MDS, targeted deepsequencing has identified a landscape of mutated genes that encode signal transduction proteins (NRAS , FLT3$I T D, C B L, J A K 2, K I T)$, transcription factors (RUNX1, ETV6), tumor suppressors genes (TP53, WT1), epigenetic modifiers (TET2, ASXL1, IDH1, IDH2, EZH2, DNMT3A), RNA splicing machinery (SF3B1, U2AF1, SRSF2, ZRSR2) and components of the cohesin complex (STAG2, RAD21, $S M C 3, S M C 1 A)[10,18,21]$. However, no mutations in these genes are detected in 10-20\% of MDS patients. In our series, using a panel of 83 myeloid related genes, we were able to detect mutations in $95 \%$ of patients with high-risk MDS and sAML. This percentage is higher than other studies focused on MDS, maybe due to our patients are high-risk and this supports the idea that in advanced stages of the disease there is a greater genomic complexity. Only 5 genes (TP53, DNMT3A, SRSF2, TET2 and $U 2 A F 1$ ) were present in more than $10 \%$ of cases. We found mutations in 30 additional genes, but in a lower frequency (Figure 1) and no mutation was found in the rest of the studied genes $(n=48)$. These results corroborate the heterogeneous landscape of MDS at the mutational level. We would also like to emphasize, that many groups do not use control tissue when NGS is performed, may be due to the increase on cost that this implies, but we have demonstrated its usefulness to discriminate germ line variations from somatic mutations. In our study, due to the availability of the CD3+ control tissue, we have been able to discard a mean of two variables per sample that had not been established as SNPs in public databases. Otherwise it would have wrongly increased the number of mutations detected per patient.

In MDS the percentage of TP53 mutations is approximately $20 \%$ [13] but in our cohort this percentage increased up to nearly $50 \%$. This fact could be explained because our cohort of patients include only high-risk MDS and sAML, which have been highly associated with complex karyotypes (46\% in our series) and it is also well known that TP53 mutations are enriched in patients with these cytogenetic characteristics [22]. Another explanation could be that the limited number of patients included in our series have influenced this percentage. Recently, some studies have demonstrated the association between mutations in TP53 and higher response rate to high doses of decitabine in AML and MDS patients [23, 24]. Although AZA and decitabine are both HMAs, we could not corroborate these results in our cohort treated with AZA. 
An explanation may be the different treatment schedules or doses used between the two drugs, as well as differences mechanisms of action of both treatments (incorporation into DNA of decitabine and incorporation into RNA and DNA of AZA) [25], or even though to specific disease characteristics of the patients treated within each study.

Due to the large amount of genetic information currently available, some groups are working in incorporating molecular data into the IPSS-R in patients with MDS [26]. As TP53 mutations have recurrently been associated with decreased OS and higher rates of AML transformation $[7,11]$, it seems to be a good candidate for being incorporated to this score. We have also corroborated this finding in our study, as TP53 mutations were the only marker that retained its significance in the multivariate analysis for PFS and almost for OS. Mutations in TP53 are also associated with poorer OS after ASCT [27, 28]. In accordance to these studies, and although in our series only 5 patients were allografted, the three patients who had TP53 mutations died in less than one year after the MDS diagnosis, whereas the two patients without TP53 alterations are still alive after more than 3 years after diagnosis.
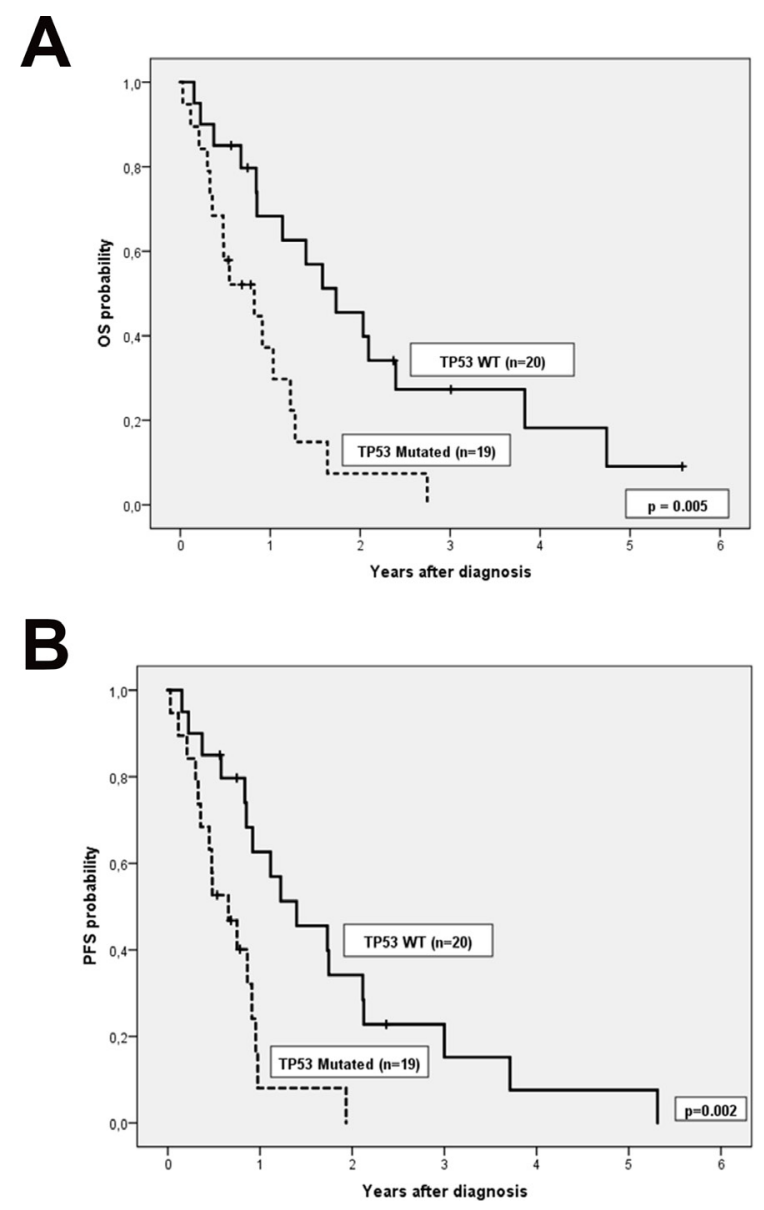

It is well established that spliceosome mutations, such as $S R S F 2$, are mutually exclusive among them but they usually coexist with mutations in epigenetic modifiers, cooperating to give rise to the MDS phenotype [29]. In our cohort we also observed this association between SRSF2 and TET2. The role of SRSF2 mutations in MDS is not yet well understood; while in some studies, these mutations have been associated with worse OS and a higher rate of transformation to AML [30], other groups have demonstrated that SRSF2 mutations do not have impact on OS [31]. In our cohort, SRSF2 mutations was an independent variable for better OS and PFS in the univariate analysis and together with TP53 mutations it allows to stratify patients into three risk group categories (Figure 3). These results have to be taken with caution as in our series, SRSF 2 mutations were associated with TET2 mutations (4/7) (which have been defined as a factor of response to HMAs [32] particularly when ASXL1 is not mutated) and none of these four patients had $A S X L 1$ mutations. Considering also the limited number of patients with SRSF2 mutations in our study, the good prognosis of SRSF2 mutations should be confirmed in a bigger independent cohort of high-risk MDS patients.
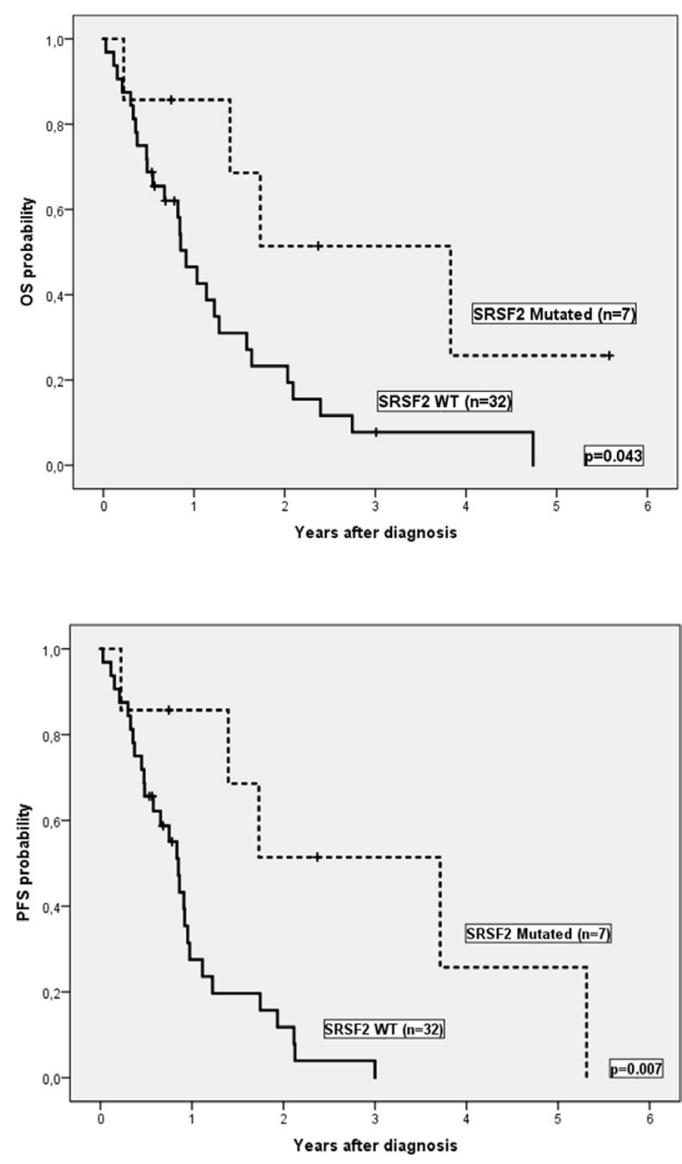

Figure 2: (A) Overall survival and (B) Progression free survival according TP53 and SRSF2 mutational status. 
There are some studies that have shown a relationship between a higher number of oncogenic mutations with an adverse outcome [20]. In our cohort we could not demonstrate this relationship (data not shown) maybe due to the high proportion of patients with TP53 mutations, which by itself gives a worse outcome to the patient.

Even though there are some studies that correlate mutational status to treatment response [23, 24, 32] we could not demonstrate this impact in our cohort. This fact could be explained by the limited number of evaluable patients for treatment response or due to differences between the designs of the studies.

Regarding MDS architecture, it has been defined that most cases of MDS are clonally heterogeneous, with a founding clone and multiple additional subclones. Using targeted deep sequencing techniques, it has become possible to find driver mutations involved in clonal evolution of $\operatorname{MDS}[10,20,33]$. Driver mutations are defined as mutations in an immature hematopoietic stem cell with capacity for self-renewal; typically involving a gene of RNA splicing or DNA methylation, that provides selective advantage and determines local clonal expansion $[7,20]$. To elucidate differential roles of mutations in MDS, we investigated clonal dynamics using targeted deep sequencing in 11 patients. Most of the mutations that we found at diagnosis were in genes that control cell cycle (TP53), DNA methylation (DNMT3A) and spliceosome machinery (SRSF2). The mean number of gene mutations in a patient with MDS tends to be higher in the high-risk subtypes, supporting the idea that some MDS stem cells gain the ability to proliferate through the accumulation of gene mutations, leading to clonal expansion and disease progression [10]. At progression, most of patients from our cohort experienced an increase in the number of mutations, their diversity and clone sizes, with alterations frequently found in the dominant clones with or without their sweeping previous clones. It has been described

A

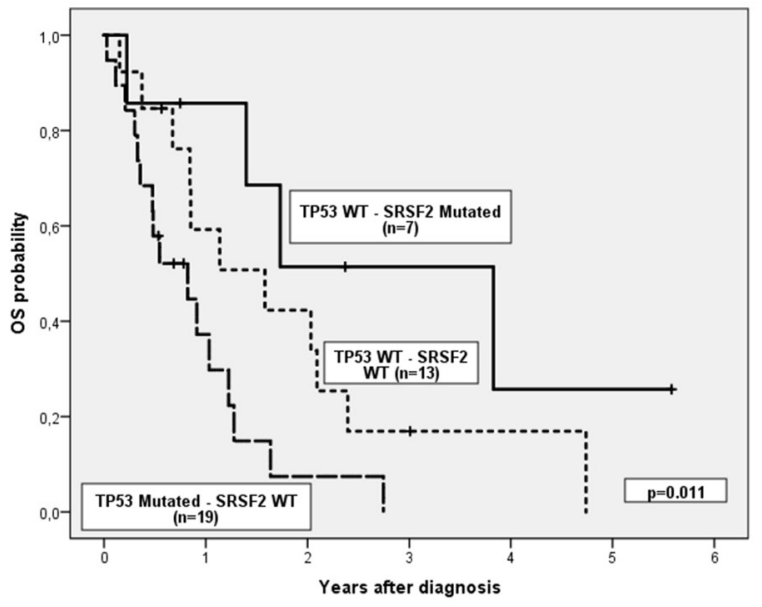

that the emergence of new driver mutations, even if they are still subclonal, can have relevant implications for the future disease evolution. In our cohort we could observe two patients with an increase in the number of mutations despite having hematological improvement, and these patients progressed faster than the other ones. Studying mutation evolution during patient's follow-up may allow to identify patients whose disease will progress faster, even before symptoms appear.

In summary, although we are aware that, compared with other studies, our series is limited by the number of studied samples, we have one of the better well studied cohorts of a homogeneous subtype of MDS, in which DNA from CD3 + cells as control tissue was available to avoid germinal variables. Our findings corroborate the higher incidence of TP53 mutations among high-risk MDS, that molecular markers such as TP53 and SRSF2 mutations provide additional prognostic data to guide clinical decisions in high-risk MDS and that the use of mutation analysis during follow up may help to identify patients who are progressing before the onset of signs of progression. All these facts emphasize the importance of introducing genetic data into prognostic models to better stratify patients at diagnosis. Nonetheless, future studies including larger cohorts of patients treated homogenously with AZA are needed to consolidate our results.

\section{MATERIALS AND METHODS}

\section{Patients and samples}

A total of 39 high-risk MDS $(n=30)$ and SAML $(n=9)$ patients, at diagnosis and after AZA treatment, were retrospectively analyzed in this study. Samples were collected from October 2009 to December 2014. Patients were diagnosed according to the 2008 World Health Organization (WHO) classification [34] in

\section{B}

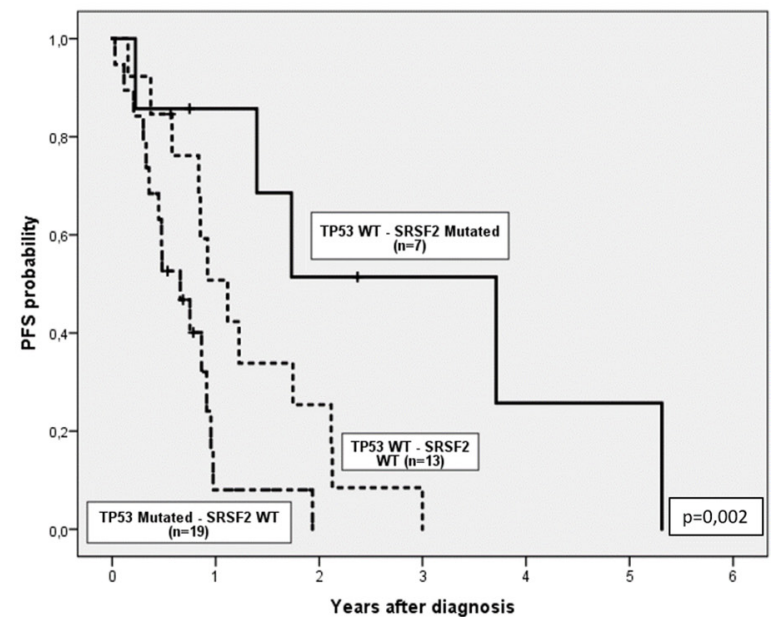

Figure 3: (A) Overall survival and (B) Progression free survival considering together TP53 and SRSF2 mutational status. 
Table 4: Differences in treatment response based on clinical characteristics and mutational status from 31 evaluable patients

\begin{tabular}{|c|c|c|c|}
\hline Variable & $\begin{array}{c}\text { Non-responders } \\
n=14(\%)\end{array}$ & $\begin{array}{c}\text { Responders } \\
n=17(\%)\end{array}$ & $p$-value \\
\hline $\begin{array}{l}\text { Age, years } \\
<70 \\
\geq 70\end{array}$ & $\begin{array}{l}5(36) \\
9(64)\end{array}$ & $\begin{array}{l}8(47) \\
9(53)\end{array}$ & 0.524 \\
\hline $\begin{array}{l}\text { Gender } \\
\text { Male } \\
\text { Female }\end{array}$ & $\begin{array}{l}9(64) \\
5(36)\end{array}$ & $\begin{array}{c}14(82) \\
3(18)\end{array}$ & 0.412 \\
\hline $\begin{array}{l}\text { WHO classification } \\
\text { RARS } \\
\text { RCDM-RS } \\
\text { RCMD } \\
\text { RAEB-1 } \\
\text { RAEB-2 } \\
\text { SAML }\end{array}$ & $\begin{array}{l}1(7) \\
1(7) \\
1(7) \\
5(36) \\
4(29) \\
2(14)\end{array}$ & $\begin{array}{l}0 \\
0 \\
4(24) \\
1(6) \\
7(41) \\
5(29)\end{array}$ & - \\
\hline $\begin{array}{l}\text { Hemoglobin level, g/dL } \\
<10 \mathrm{~g} / \mathrm{dL} \\
\geq 10 \mathrm{~g} / \mathrm{dL}\end{array}$ & $\begin{array}{l}12(86) \\
2(14)\end{array}$ & $\begin{array}{l}10(59) \\
7(41)\end{array}$ & 0.132 \\
\hline $\begin{array}{l}\text { Leukocyte count, } \times 10^{9} / \mathrm{L} \\
<4 \times 10^{9} / \mathrm{L} \\
>4 \times 10^{9} / \mathrm{L} \text { and }<11 \times 10^{9} / \mathrm{L} \\
\geq 11 \times 10^{9} / \mathrm{L}\end{array}$ & $\begin{array}{l}8(57) \\
6(43) \\
0\end{array}$ & $\begin{array}{l}14(82) \\
2(12) \\
1(6)\end{array}$ & 0.112 \\
\hline $\begin{array}{l}\text { Platelet count, } \times 10^{9} / \mathrm{L} \\
<100 \times 10^{9} / \mathrm{L} \\
\geq 100 \times 10^{9} / \mathrm{L}\end{array}$ & $\begin{array}{l}10(71) \\
4(29)\end{array}$ & $\begin{array}{c}12(71) \\
5(29)\end{array}$ & 1 \\
\hline $\begin{array}{l}\text { Neutrophil count, } \times 10^{9} / \mathrm{L} \\
<0.8 \times 10^{9} / \mathrm{L} \\
\geq 0.8 \times 10^{9} / \mathrm{L}\end{array}$ & $\begin{array}{c}3(23) \\
10(77)\end{array}$ & $\begin{array}{l}8(47) \\
9(53)\end{array}$ & 0.177 \\
\hline $\begin{array}{l}\text { Blasts in } \mathrm{PB}, \% \\
<5 \% \\
\geq 5 \%\end{array}$ & $\begin{array}{l}10(71) \\
4(29)\end{array}$ & $\begin{array}{c}15(94) \\
1(6)\end{array}$ & 0.157 \\
\hline $\begin{array}{l}\text { Blasts in BM, \% } \\
<20 \% \\
\geq 20 \%\end{array}$ & $\begin{array}{l}12(86) \\
2(14)\end{array}$ & $\begin{array}{l}11(65) \\
6(35)\end{array}$ & 0.240 \\
\hline $\begin{array}{l}\text { Cytogenetics } \\
\text { Normal karyotype } \\
\text { Abnormal karyotype }\end{array}$ & $\begin{array}{c}3(21) \\
11(79)\end{array}$ & $\begin{array}{c}4(24) \\
13(76)\end{array}$ & 1 \\
\hline $\begin{array}{l}\text { IPSS risk group } \\
\text { Intermediate-1 } \\
\text { Intermediate-2 } \\
\text { High }\end{array}$ & $\begin{array}{l}2(14) \\
7(50) \\
5(36)\end{array}$ & $\begin{array}{l}2(12) \\
7(41) \\
8(47)\end{array}$ & 0.816 \\
\hline $\begin{array}{l}\text { IPSS-R risk group } \\
\text { Intermediate } \\
\text { High } \\
\text { Very High }\end{array}$ & $\begin{array}{l}3(21) \\
5(36) \\
6(43)\end{array}$ & $\begin{array}{l}2(12) \\
6(35) \\
9(53)\end{array}$ & 0.739 \\
\hline $\begin{array}{l}\text { TP53 mutational status } \\
\text { Wild-type } \\
\text { Mutant }\end{array}$ & $\begin{array}{l}8(57) \\
6(43)\end{array}$ & $\begin{array}{l}10(59) \\
7(41)\end{array}$ & 0.925 \\
\hline
\end{tabular}


DNMT3A mutational status
Wild-type
$11(79)$
$3(21)$
$12(71)$
$5(29)$
$11(79)$
$3(21)$
$14(82)$
3 (18)
Mutant
TET2 mutational status
Wild-type
$11(79)$
$15(88)$
$3(21)$
2 (12)
$14(100)$
$14(82)$
$3(18)$
0.698
1
0.636
0.232
Wild-type
0

BM: bone marrow; PB: peripheral blood; RAEB-1: refractory anemia with excess of blasts-1; RAEB-2: refractory anemia with excess of blasts-2; RARS: refractory anemia with ring sideroblasts; RCMD: refractory cytopenia with multilineage dysplasia; RCMD-RS: refractory cytopenia with multilineage dysplasia and ring sideroblasts; sAML: secondary acute myeloid leukemia.

Table 5: List of affected genes in MDS patients that were studied at diagnosis, response and/or at time of progression/ relapse $(n=11)$

\begin{tabular}{|c|c|c|c|c|c|c|c|c|}
\hline & Data at diagnosis & & & Data at response & & & Data at progression/ relapse & \\
\hline $\begin{array}{l}\text { Pt ID and } \\
\text { DX }\end{array}$ & Alteration & VAF & Time & Alteration & VAF & Time & Alteration & VAF \\
\hline Pt ID4 & DNMT3A c.2347T $>$ A & $31 \%$ & & * & & $6 \mathrm{M}$ & DNMT3A c. $2347 \mathrm{~T}>\mathrm{A}$ & $47.1 \%$ \\
\hline \multirow[t]{3}{*}{ RAEB-1 } & $\mathrm{EZH} 2$ c. $371 \mathrm{~T}>\mathrm{A}$ & $37.6 \%$ & & & & relapse & $\mathrm{EZH} 2$ c. $371 \mathrm{~T}>\mathrm{A}$ & $42.5 \%$ \\
\hline & TP53 c.745T $>C$ & $32.3 \%$ & & & & & TP53 c.745T $>\mathrm{C}$ & $42.9 \%$ \\
\hline & TP53 с. $637 \mathrm{G}>\mathrm{A}$ & $35.3 \%$ & & & & & TP53 с. $637 \mathrm{G}>\mathrm{A}$ & $47.2 \%$ \\
\hline Pt ID16 & TP53 c.713C $>$ T & $38.8 \%$ & & & & $6 \mathrm{M}$ & TP53 c.713C $>$ T & $34 \%$ \\
\hline RAEB-1 & TP53 c. $395 \mathrm{~T}>\mathrm{C}$ & $34.7 \%$ & & & & progression & TP53 c. $395 \mathrm{~T}>\mathrm{C}$ & $34 \%$ \\
\hline Pt ID7 & $\mathrm{EZH} 2$ c. $2077 \mathrm{~T}>\mathrm{A}$ & $79.4 \%$ & $3 \mathrm{M}$ & $\mathrm{EZH} 2$ c. $2077 \mathrm{~T}>\mathrm{A}$ & $80.7 \%$ & $6 \mathrm{M}$ & $\mathrm{EZH} 2$ c. $2077 \mathrm{~T}>\mathrm{A}$ & $72.6 \%$ \\
\hline RAEB-1 & & & $\begin{array}{l}\text { Partial } \\
\text { response }\end{array}$ & IDH1 c394G $>$ A & $27.4 \%$ & progression & IDH1 c394G >A & $35.3 \%$ \\
\hline Pt ID11 & TP53 c.371_372insC & $68.6 \%$ & & * & & $2 \mathrm{M}$ & TP53 c.371_372insC & $38.8 \%$ \\
\hline RAEB-1 & & & & & & progression & NF1 c.282_283insG & $27 \%$ \\
\hline Pt ID32 & BCOR c.2076_2077insA & $62.4 \%$ & $12 \mathrm{M}$ & BCOR c.2752G $>$ A & $51.2 \%$ & $27 \mathrm{M}$ & BCOR c.2076_2077insA & $79.3 \%$ \\
\hline \multirow[t]{5}{*}{ RAEB-2 } & $\begin{array}{c}\text { BCORL1 } \\
\text { c.4134_4135insA }\end{array}$ & $68.2 \%$ & Complete & $\mathrm{U} 2 \mathrm{AF} 1 \mathrm{c} .101 \mathrm{G}>\mathrm{A}$ & $34.6 \%$ & Relapse & $\begin{array}{c}\text { BCORL1 } \\
\text { c.4134_4135insA }\end{array}$ & $84.6 \%$ \\
\hline & $\begin{array}{c}\text { STAG2 } \\
\text { c.3616_3617insCAAT }\end{array}$ & $65.8 \%$ & response & & & & $\begin{array}{c}\text { STAG2 } \\
\text { c.3616_3617insCAAT }\end{array}$ & $84.1 \%$ \\
\hline & $\mathrm{U} 2 \mathrm{AF} 1$ c. $101 \mathrm{G}>\mathrm{A}$ & $39.7 \%$ & & & & & $\mathrm{U} 2 \mathrm{AF} 1$ c. $101 \mathrm{G}>\mathrm{A}$ & $46.8 \%$ \\
\hline & & & & & & & $\begin{array}{c}\text { GATA2 } \\
\text { c.569_570insGCCC }\end{array}$ & $24.1 \%$ \\
\hline & & & & & & & NF1 c.1067T $>C$ & $42.6 \%$ \\
\hline $\begin{array}{l}\text { Pt ID21 } \\
\text { RAEB-2 }\end{array}$ & TP53 c.743C $>$ T & $48.2 \%$ & & $*$ & & $\begin{array}{l}12 \mathrm{M} \\
\text { relapse }\end{array}$ & 0 & \\
\hline Pt ID13 & 0 & & $24 \mathrm{M}$ & 0 & & $36 \mathrm{M}$ & LUC7L2 c.1300A $>C$ & $38.9 \%$ \\
\hline RAEB-2 & & & response & & & progression & TERT c.1234G $>$ A & $40.9 \%$ \\
\hline
\end{tabular}




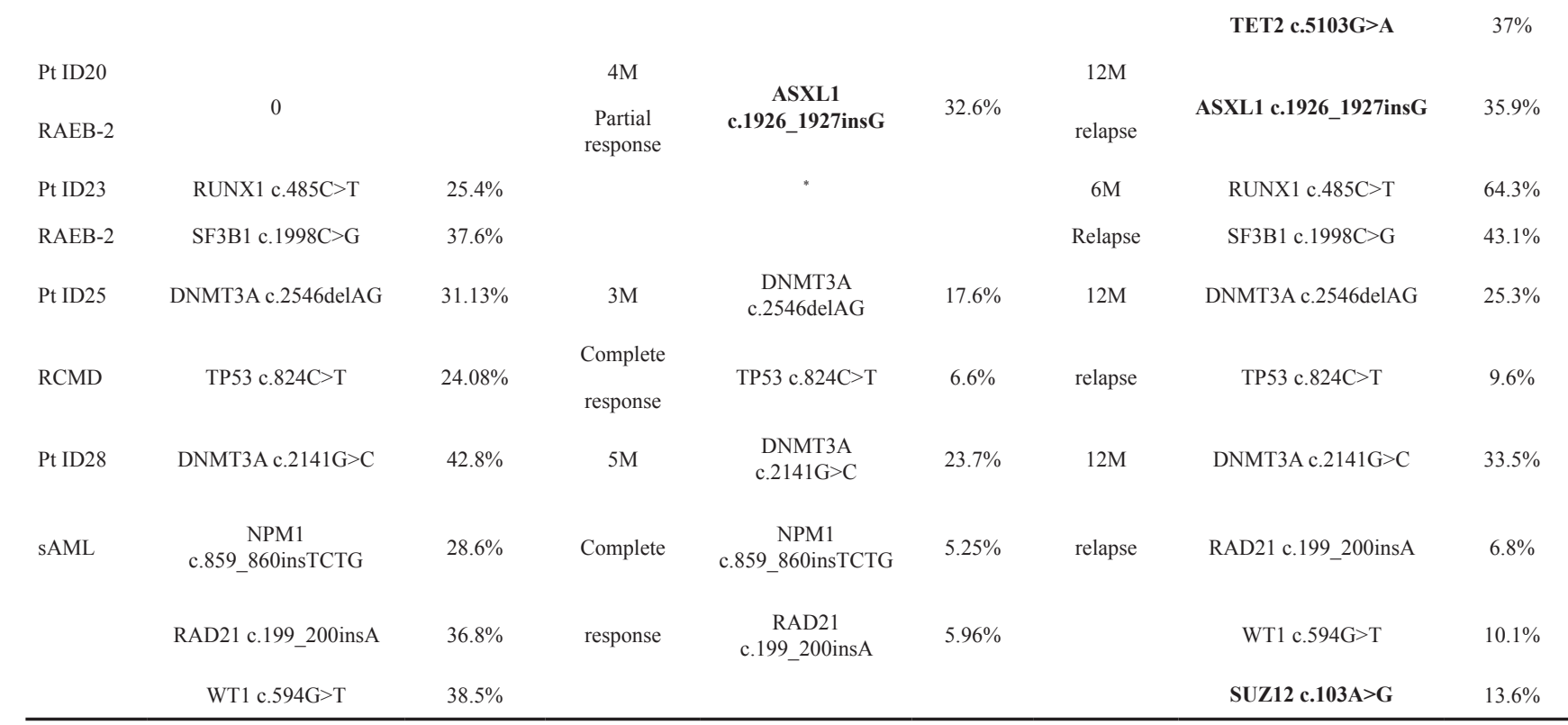

DX: diagnosis; M: month; Pt: patient; RAEB-1: refractory anemia with excess of blasts-1; RAEB-2: refractory anemia with excess of blasts-2; RCMD: refractory cytopenia with multilineage dysplasia; SAML: secondary acute myeloid leukemia; VAF: Variant allele frequency.

"No data at that point.

Genes that differ from the affected at time of diagnosis are highlighted in bold.

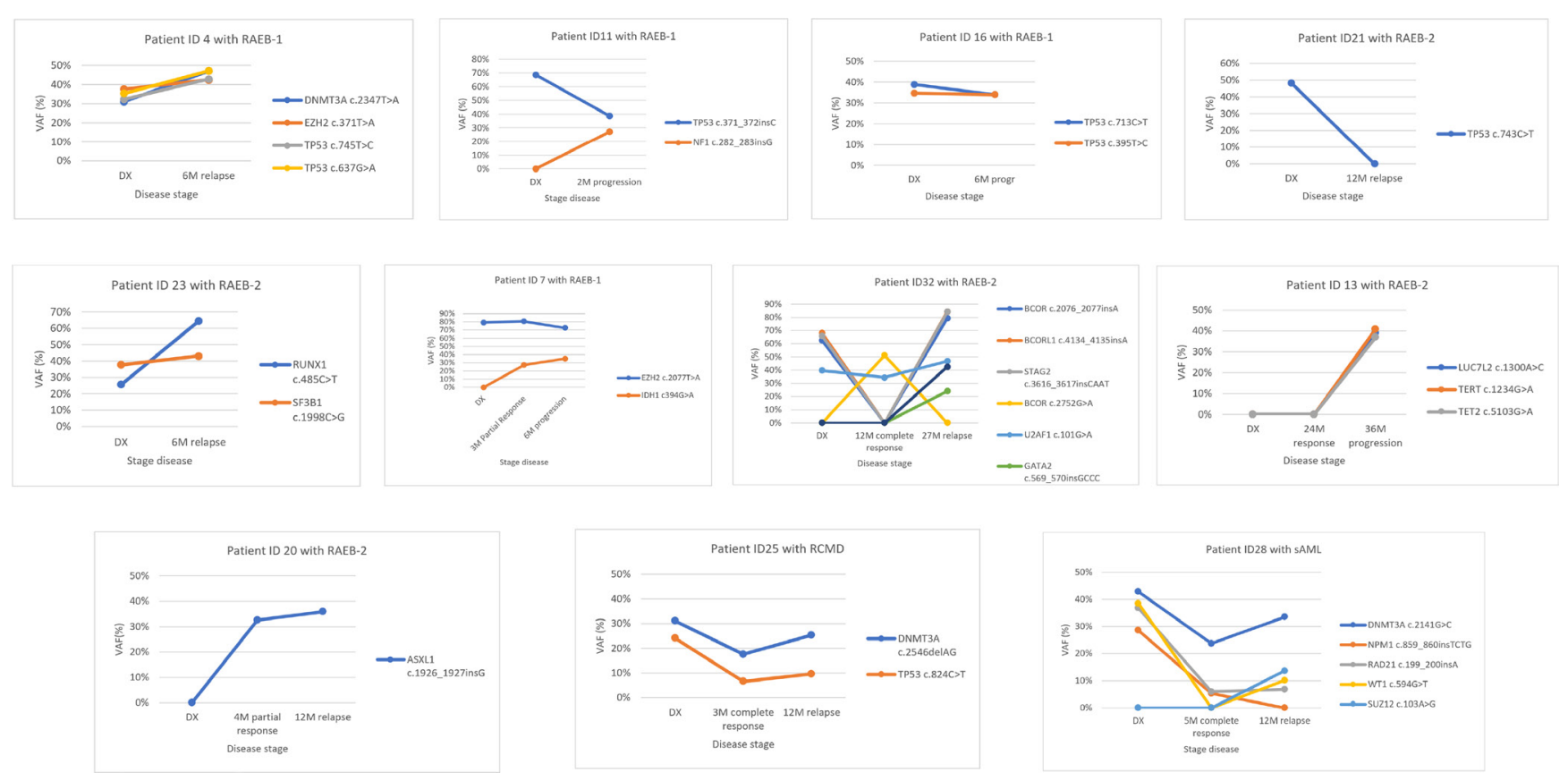

Figure 4: Variant allele frequency evolution during disease follow-up in eleven patients treated with 5-azacytidine. In 5 patients (ID4, ID11, ID16, ID21 and ID23) samples were available at diagnosis (DX) and relapse/progression. In 6 patients (ID7, ID13, ID20, ID25, ID28 and ID32) samples were available at diagnosis, response and relapse/progression. In both cases different patterns can be seen: Model 1: The variant allele frequency (VAF) of mutations, or the number of mutations, decreases on response and increases at progression (patient ID4, ID11, ID13, ID23, ID 25, ID28 and ID32). Model 2: Mutation's VAF, or the number of mutations, increases on response indicating the progression of the disease even though an improvement of hematological features (patient ID7 and ID20) or no change has been seen between diagnosis and progression (ID16). Model 3: Mutation's VAF, or the number of mutations, decreases or disappears on disease progression indicating that the cause of progression is not due to the mutations found at diagnosis (patient ID21). 
different hospitals from the CETLAM Group, and were treated uniformly with AZA $\left(75 \mathrm{mg} / \mathrm{m}^{2}\right.$ per day for 7 days, 5-2-2, every 4 weeks). All patients received AZA during their disease evolution and five patients were allografted after AZA treatment. Response to treatment was assessed using the International Working Group (IWG) Response Criteria [35]. Briefly, patients in a complete response (CR), partial response (PR), marrow $\mathrm{CR}$ (mCR) or hematologic improvement (HI) after six months of treatment were considered as "responders", while patients who had stable disease, no response or disease progression were considered as "non-responders". Study approval was obtained from Ethical Committee for Clinical Research from Hospital Germans Trias i Pujol. Informed consent was given by all patients, in accordance with the Declaration of Helsinki.

\section{Cytogenetics}

Conventional G-banding cytogenetics was performed on bone marrow samples at diagnosis in each center and karyotypes were described according to the International System for Human Cytogenetic Nomenclature 2013 [36].

\section{DNA samples}

Samples were collected at diagnosis for all 39 patients and at time of response and/or progression in 11 patients, all these samples were sent to a reference laboratory. Whole bone marrow samples were used for the targeted deep sequencing analysis. In 21 out of 39 patients, peripheral $\mathrm{CD} 3+\mathrm{T}$ lymphocytes were purified with immunomagnetic separation (Miltenyi Biotec, Bergisch Gladbach, Germany) according to the manufacturer's recommendations and were used as control tissue to discriminate germ line variations from somatic mutations. Genomic DNA was extracted with QiaAmp DNA Blood Mini kit (Qiagen, Hilden, Germany) and quantified using Quant-iT PicoGreen dsDNA Assay Kit (Invitrogen, CA, USA).

\section{Targeted deep sequencing}

Targeted deep-sequencing of a panel of 83 myeloid-related genes was performed in all samples (Supplementary Table 1). Indexed libraries were prepared with $1 \mu \mathrm{g}$ of double strand genomic DNA using the Kapa Library Preparation Kit (Kapa Biosystems, MA, USA). Custom target capture enrichment using the SeqCap EZ capture chemistry (Nimblegen, Roche, Basel, Switzerland) was performed on pools of 8 libraries. Multiplexed captured libraries were sequenced on an Illumina MiSeq following a $150 \mathrm{bp}$ paired-end reads standard protocol.

\section{Targeted sequencing data analysis}

Sequencing data were analyzed using the commercial softwares MiSeq Reporter and Variant Studio (Illumina, CA, USA). High-probability oncogenic mutations were called after eliminating sequencing and mapping errors and after discarding variants located in high variable regions, with low coverage $(<20$ reads of the variant) or with a variant allele frequency (VAF) $<10 \%$ for single nucleotide variants (SNVs) and $<15 \%$ for insertions and deletions (indels) to ensure they were not technical artefacts. VAF was calculated as the number of the variant reads divided by the total number of reads for that position. Single nucleotide polymorphisms (SNPs) described on human genetic variation databases were also excluded.

The information obtained from patient-specific control tissue was also used to confirm SNPs filtering strategy when available. The remaining variants were considered as candidate somatic mutations, and were finally tagged as oncogenic, based on the information derived from the literature and/or on the information given by in silico predictors (data are available in SRA with SRP133179 reference).

\section{Statistical analysis}

Baseline characteristics were described as frequency and percentage for categorical variables and median and range for quantitative variables. Comparisons of categorical variables between patient subsets were compared using $\chi^{2}$ or Fisher's exact test, when appropriate, while median test was used to compare continuous variables. OS was defined as time from diagnosis to the last follow-up or death from any cause and progression free survival (PFS) as time from diagnosis to progression or death related to disease [35]. Patients who underwent an ASCT were censored at that time for OS and PFS analysis. Survival curves were performed using the Kaplan-Meier method and log-rank test was used for comparisons between groups. Multivariate analysis was performed using Cox proportional-hazards regression model, considering Wald Backward as selection method. Two-sided $P$ values $<0.05$ were considered as statistically significant. The statistical package SPSS, version 24.0 (SPSS Inc., Chicago, IL, USA) was used for all analyses.

\section{Author contributions}

J.Ba. and L.Z. were the designers and promoters of the study. J.Ba., B.X., M.T., C.P., D.V., R.G., S.B., F.V-LL., A.G. and E.F. enrolled patients in the study and collected clinical data. J.Bo. and M.J.J. were in charge of the data base. M.C., S.M. and L.Z. performed sample preparation and sequencing. M.C., L.P. and L.Z. analyzed 
sequencing data. O.G. performed statistical analysis. M.C. wrote the manuscript, and all the authors reviewed and approved the final manuscript.

\section{ACKNOWLEDGMENTS}

The authors would like to thank Diana Domínguez for her technical assistance and to the IGTP Genomic Core Facility and staff, Maria Pilar Armengol and Anna Oliveira, for their contribution to this publication.

\section{CONFLICTS OF INTEREST}

The authors have no potential conflicts of interest to disclose.

\section{FUNDING}

This work was supported in part by a grant from Instituto de Salud Carlos III, Ministerio de Sanidad y Consumo, Spain (PI 11/02519); 2014 SGR225 (GRE) Generalitat de Catalunya; Fundació Josep Carreras and Celgene Spain.

\section{REFERENCES}

1. Arber DA, Orazi A, Hasserjian R, Thiele J, Borowitz MJ, Le Beau MM, Bloomfield CD, Cazzola M, Vardiman JW. The 2016 revision to the World Health Organization classification of myeloid neoplasms and acute leukemia. Blood. 2016; 127:2391-405. https://doi.org/10.1182/ blood-2016-03-643544.

2. Tefferi A, Vardiman J. Myelodysplastic syndromes. N Engl J Med. 2009; 361:1872-85. https://doi.org/10.1007/ s00282-996-0363-7.

3. Greenberg PL, Tuechler H, Schanz J, Sanz G, Garciamanero G, Solé F, Bennett JM, Bowen D, Fenaux P, Dreyfus F, Kantarjian H, Kuendgen A, Levis A, et al. Revised International Prognostic Scoring System for Myelodysplastic Syndromes. Blood. 2012; 120:2454-65. https://doi.org/10.1182/blood-2012-03-420489.

4. Larsson CA, Cote G, Quintás-Cardama A. The changing mutational landscape of acute myeloid leukemia and myelodysplastic syndrome. Mol Cancer Res. 2013; 11:81527. https://doi.org/10.1158/1541-7786.MCR-12-0695.

5. Graubert T, Walter MJ. Genetics of Myelodysplastic Syndromes:New Insights. Hematology. 2011; 2011:543-9. https://doi.org/10.1182/asheducation-2011.1.543.

6. Raza A, Galili N. The genetic basis of phenotypic heterogeneity in myelodysplastic syndromes. Nat Rev Cancer. 2012; 12:849-59. https://doi.org/10.1038/nrc3321.

7. Cazzola M, Della Porta MG, Malcovati L. The genetic basis of myelodysplasia and its clinical relevance. Blood. 2013; 122:4021-34. https://doi.org/10.1182/ blood-2013-09-381665.
8. Yoshida K, Sanada M, Shiraishi Y, Nowak D, Nagata Y, Yamamoto R, Sato Y, Sato-Otsubo A, Kon A, Nagasaki M, Chalkidis G, Suzuki Y, Shiosaka M, et al. Frequent pathway mutations of splicing machinery in myelodysplasia. Nature. 2011; 478:64-9. https://doi.org/10.1038/nature10496.

9. Nikoloski G, Van Der Reijden BA, Jansen JH. Mutations in epigenetic regulators in myelodysplastic syndromes. Int J Hematol. 2012; 95:8-16. https://doi.org/10.1007/ s12185-011-0996-3.

10. Haferlach T, Nagata Y, Grossmann V, Okuno Y, Bacher U, Nagae G, Schnittger S, Sanada M, Kon A, Alpermann T, Yoshida K, Roller A, Nadarajah N, et al. Landscape of genetic lesions in 944 patients with myelodysplastic syndromes. Leukemia. 2013; 28:241-7. https://doi. org/10.1038/leu.2013.336.

11. Bejar R, Stevenson K, Abdel-Wahab O, Galili N, Nilsson B, Garcia-Manero G, Kantarjian H, Raza A, Levine RL, Neuberg D, Ebert BL. Clinical effect of point mutations in myelodysplastic syndromes. N Engl J Med. 2011; 364:2496-506. https://doi.org/10.1056/NEJMoa1013343.

12. Garcia-Manero G. Myelodysplastic syndromes:2015 Update on diagnosis, risk-stratification and management. Am J Hematol. 2015; 90:831-41. https://doi.org/10.1002/ ajh.24102.

13. Gangat N, Patnaik MM, Tefferi A. Myelodysplastic syndromes:Contemporary review and how we treat. Am J Hematol. 2016; 91:76-89. https://doi.org/10.1002/ajh.24253.

14. Fenaux P, Mufti GJ, Hellstrom-Lindberg E, Santini V, Finelli C, Giagounidis A, Schoch R, Gattermann N, Sanz G, List A, Gore SD, Seymour JF, Bennett JM, et al. Efficacy of azacitidine compared with that of conventional care regimens in the treatment of higher-risk myelodysplastic syndromes:a randomised, open-label, phase III study. Lancet Oncol. 2009; 10:223-32. https://doi.org/10.1016/ S1470-2045(09)70003-8.

15. Gore SD, Fenaux P, Santini V, Bennett JM, Silverman LR, Seymour JF, Hellström-Lindberg E, Swern AS, Beach CL, List AF. A multivariate analysis of the relationship between response and survival among patients with higherrisk myelodysplastic syndromes treated within azacitidine or conventional care regimens in the randomized AZA001 trial. Haematologica. 2013; 98:1067-72. https://doi. org/10.3324/haematol.2012.074831.

16. Itzykson R, Kosmider O, Cluzeau T, Mansat-De Mas V, Dreyfus F, Beyne-Rauzy O, Quesnel B, Vey N, Gelsi-Boyer V, Raynaud S, Preudhomme C, Adès L, Fenaux P, et al. Impact of TET2 mutations on response rate to azacitidine in myelodysplastic syndromes and low blast count acute myeloid leukemias. Leukemia. 2011; 25:1147-52. https:// doi.org/10.1038/leu.2011.71.

17. Unnikrishnan A, Papaemmanuil E, Beck D, Deshpande NP, Verma A, Kumari A, Woll PS, Richards LA, Knezevic K, Chandrakanthan V, Thoms JAI, Tursky ML, Huang Y, et al. Integrative Genomics Identifies the Molecular Basis of Resistance to Azacitidine Therapy in Myelodysplastic 
Syndromes. Cell Rep. 2017; 20:572-85. https://doi. org/10.1016/j.celrep.2017.06.067.

18. Nybakken GE, Bagg A. The Genetic Basis and Expanding Role of Molecular Analysis in the Diagnosis , Prognosis, and Therapeutic Design for Myelodysplastic Syndromes. J Mol Diagn. 2014; 16:145-58. https://doi.org/10.1016/j. jmoldx.2013.11.005.

19. Pellagatti A, Boultwood J. The molecular pathogenesis of the myelodysplastic syndromes. Eur J Haematol. 2015; 95:3-15. https://doi.org/10.1111/ejh.12515.

20. Papaemmanuil E, Gerstung M, Malcovati L, Tauro S, Gundem G, Van Loo P, Yoon CJ, Ellis P, Wedge DC, Pellagatti A, Shlien A, Groves MJ, Forbes SA, et al. Clinical and biological implications of driver mutations in myelodysplastic syndromes. Blood. 2013; 122:3616-27. https://doi.org/10.1182/blood-2013-08-518886.

21. Kulasekararaj AG, Mohamedali AM, Mufti GJ. Recent advances in understanding the molecular pathogenesis of myelodysplastic syndromes. Br J Haematol. 2013; 162:587605. https://doi.org/10.1111/bjh.12435.

22. Sallman DA, Komrokji R, Vaupel C, Cluzeau T, Geyer SM, McGraw KL, Al Ali NH, Lancet J, McGinniss MJ, Nahas S, Smith AE, Kulasekararaj A, Mufti G, et al. Impact of TP53 mutation variant allele frequency on phenotype and outcomes in myelodysplastic syndromes. Leukemia. 2016; 30:666-73. https://doi.org/10.1038/leu.2015.304.

23. Chang CK, Zhao YS, Xu F, Guo J, Zhang Z, He Q, Wu D, Wu LY, Su JY, Song LX, Xiao C, Li X. TP53 mutations predict decitabine-induced complete responses in patients with myelodysplastic syndromes. Br J Haematol. 2017; 176:600-8. https://doi.org/10.1111/bjh.14455.

24. Welch JS, Petti AA, Miller CA, Fronick CC, O'Laughlin M, Fulton RS, Wilson RK, Baty JD, Duncavage EJ, Tandon B, Lee YS, Wartman LD, Uy GL, et al. TP53 and Decitabine in Acute Myeloid Leukemia and Myelodysplastic Syndromes. N Engl J Med. 2016; 375:2023-36. https://doi.org/10.1056/ NEJMoa1605949.

25. Diesch J, Zwick A, Garz AK, Palau A, Buschbeck M, Götze KS. A clinical-molecular update on azanucleosidebased therapy for the treatment of hematologic cancers. Clin Epigenetics. 2016; 8:71. https://doi.org/10.1186/ s13148-016-0237-y.

26. Nazha A, Narkhede M, Radivoyevitch T, Seastone DJ, Patel BJ, Gerds AT, Mukherjee S, Kalaycio M, Advani A, Przychodzen B, Carraway HE, Maciejewski JP, Sekeres MA. Incorporation of molecular data into the Revised International Prognostic Scoring System in treated patients with myelodysplastic syndromes. Leukemia. 2016; 30:2214-20. https://doi.org/10.1038/leu.2016.138.

27. Lindsley RC, Saber W, Mar BG, Redd R, Wang T, Haagenson MD, Grauman PV, Hu ZH, Spellman SR, Lee SJ, Verneris MR, Hsu K, Fleischhauer K, et al. Prognostic Mutations in Myelodysplastic Syndrome after Stem-Cell Transplantation. N Engl J Med. 2017; 376:536-47. https:// doi.org/10.1056/NEJMoa1611604.
28. Bejar R, Stevenson KE, Caughey B, Lindsley RC, Mar BG, Stojanov P, Getz G, Steensma DP, Ritz J, Soiffer R, Antin JH, Alyea E, Armand P, et al. Somatic mutations predict poor outcome in patients with myelodysplastic syndrome after hematopoietic stem-cell transplantation. J Clin Oncol. 2014; 32:2691-8. https://doi.org/10.1200/ JCO.2013.52.3381.

29. Visconte V, Makishima H, Maciejewski J, Tiu R. Emerging roles of the spliceosomal machinery in myelodysplastic syndromes and other hematological disorders. Leukemia. 2012; 26:2447-54. https://doi.org/10.1038/leu.2012.130.

30. Thol F, Kade S, Schlarmann C, Löffeld P, Morgan M, Krauter J, Wlodarski MW, Kölking B, Wichmann M, Görlich K, Göhring G, Bug G, Ottmann O, et al. Frequency and prognostic impact of mutations in SRSF2, U2AF1, and ZRSR2 in patients with myelodysplastic syndromes. Blood. 2012; 119:3578-84. https://doi.org/10.1182/ blood-2011-12-399337.

31. Bejar R, Stevenson KE, Caughey BA, Abdel-Wahab O, Steensma DP, Galili N, Raza A, Kantarjian H, Levine RL, Neuberg D, Garcia-Manero G, Ebert BL. Validation of a prognostic model and the impact of mutations in patients with lower-risk myelodysplastic syndromes. J Clin Oncol. 2012; 30:3376-82. https://doi.org/10.1200/ JCO.2011.40.7379.

32. Bejar R, Lord A, Stevenson K, Bar-Natan M, Pérez-Ladaga A, Zaneveld J, Wang H, Caughey B, Stojanov P, Getz G, Garcia-Manero G, Kantarjian H, Chen R, et al. TET2 mutations predict response to hypomethylating agents in myelodysplastic syndrome patients. Blood. 2014; 124:270512. https://doi.org/10.1182/blood-2014-06-582809.

33. Walter MJ, Shen D, Shao J, Ding L, White BS, Kandoth C, Miller CA, Niu B, McLellan MD, Dees ND, Fulton $\mathrm{R}$, Elliot $\mathrm{K}$, Heath $\mathrm{S}$, et al. Clonal diversity of recurrently mutated genes in myelodysplastic syndromes. Leukemia. 2013; 27:1275-82. https://doi.org/10.1038/leu.2013.58.

34. Vardiman JW, Thiele J, Arber DA, Brunning RD, Borowitz MJ, Porwit A, Harris NL, Le Beau MM, Hellström-Lindberg E, Tefferi A, Bloomfield CD. The 2008 revision of the WHO classification of myeloid neoplasms and acute leukemia: rationale and important changes. Blood. 2009; 114:937-51. https://doi.org/10.1182/blood-2009-03-209262.

35. Cheson BD, Greenberg PL, Bennett JM, Lowenberg B, Wijermans PW, Nimer SD, Pinto A, Beran M, De Witte TM, Stone RM, Mittelman M, Sanz GF, Gore SD, et al. Clinical application and proposal for modification of the International Working Group (IWG) response criteria in myelodysplasia. Blood. 2006; 108:419-25. https://doi. org/10.1182/blood-2005-10-4149.

36. Simons A, Shaffer LG, Hastings RJ. Cytogenetic Nomenclature: Changes in the ISCN 2013 Compared to the 2009 Edition. Cytogenet Genome Res. 2013; 141:1-6. https://doi.org/10.1159/000353118. 